\title{
Refuerzo de vigas de madera mediante perfiles metálicos situados en la cara superior
}

\section{Bending reinforcement of timber beams with steel cross sections on the upper face}

\author{
$\underline{\text { C. González-Bravo }}^{(*)}$, F. Arriaga-Martitegui(**), L. Maldonado-Ramos ${ }^{(* *)}$, R. Díez-Barra(***)
}

Recepción/Received: 10-IV-08

Aceptación/Accepted: 30-IX-08

Publicado online/Online publishing: 04-III-10

\section{RESUMEN}

Se describe un procedimiento para el refuerzo de viguetas de madera en edificios antiguos utilizando perfiles de acero con sección en $U$ conectados a la madera con tirafondos y situados en la cara superior. Se realizaron ensayos a flexión sobre 3 grupos de 10 piezas obteniendo la rigidez y la capacidad de carga. El primero compuesto por piezas de madera laminada encolada de abeto con una sección de 180 × 200 mm; el segundo con madera aserrada de pino silvestre; y el tercero con madera del género Pinus con una sección de 130 x 150 mm, con 120 años de antigüedad. Cada grupo se dividió a su vez en dos grupos de 5 piezas. El primer subgrupo se ensayó sin refuerzo y el segundo con el refuerzo metálico. El refuerzo incrementa la rigidez entre el 45 y el $98 \%$ y la capacidad de carga entre el 27 y el $58 \%$.

Palabras-clave: madera, acero, método de los elementos finitos, refuerzo, rehabilitación.
SUMMARY

A procedure for the reinforcement of timber floor joists in ancient buildings using steel $U$ shape cross sections screwed to timber from the upper side is described. Bending tests of 3 groups of 10 beams were carried out obtaining the stiffness and load carrying capacity. The first one was composed by pieces of glued laminated timber of Spruce with $180 \times 200 \mathrm{~mm}$ cross section; the second one was of Scots pine sawn timber with the same cross section; and the third one was 120 years old solid timber beams of genus Pine with $130 \times 150 \mathrm{~mm}$ cross section. Each group was divided in two groups of 5 beams. The first sub-group was tested without reinforcement and the second one was tested with the steel reinforcement. The reinforcement increases the stiffness from 45 to $98 \%$ and the load carrying capacity from 27 to $58 \%$.

Keywords: timber, steel, finite elements method, upgrading, rehabilitation.

(*) Universidad Antonio de Nebrija (Madrid, España).

(**) Universidad Politécnica (Madrid, España).

$(* * *)$ CIFOR-INIA (Madrid, España). 


\section{INTRODUCCIÓN}

El objetivo de este trabajo es el análisis del comportamiento del refuerzo de vigas de madera mediante la utilización de perfiles metálicos conectados a la madera por atornillado desde la cara superior, sin necesidad de intervenir desde la planta inferior.

En obras de rehabilitación de edificios con estructura de madera es frecuente encontrar la necesidad de aumentar la capacidad portante a flexión de los forjados debido a la pérdida de resistencia y rigidez causada por el efecto de ataques de insectos xilófagos. En otras ocasiones, esta necesidad se debe a los mayores requerimientos de la normativa actual (en cargas o en limitaciones de la deformación) generalmente por un cambio de uso del edificio.

En la práctica de la construcción existen varios procedimientos para el refuerzo de vigas de madera a flexión que pueden resumirse agrupados en los cuatro bloques que se comentan a continuación (1). El primero consiste en la mejora de la estructura mediante la incorporación de un nuevo sistema estructural de apoyo (apeos mediante tornapuntas o vigas que acorten la luz de la estructura). Lógicamente, este sistema casi siempre requiere la actuación desde la planta inferior y exige una cierta pérdida de altura libre en los locales.

Otra posibilidad es el aumento de la rigidez y capacidad resistente de las piezas mediante la incorporación de elementos de refuerzo (materiales compuestos, metales o madera), generalmente encolados a la pieza original (con frecuencia con formulaciones epoxi). Esta técnica es muy utilizada en la recuperación o consolidación de partes de las piezas de madera que han sido destruidas por daños de origen biológico (2-5). Es el caso frecuente de las cabezas de vigas con pudrición en los apoyos en los muros. Como procedimiento para el refuerzo de piezas en flexión es habitual su empleo para aumentar la sección de las vigas encolando piezas en la cara superior (6). La introducción de armaduras dentro de la sección de la pieza de madera ha sido estudiada experimentalmente desde hace tiempo. Algunos autores (7) comprobaron la eficacia de un refuerzo con barras de materiales compuestos y con cable de acero en vigas a flexión. La capacidad de carga aumentaba entre un 32 y un $42 \%$ y la rigidez aumentaba con factor entre un 1,31 y un 1,69 . Sin embargo, el procedimiento resulta demasiado complejo para una aplicación en obra.

La utilización de fibra de carbono y chapas de acero ha sido estudiada en el refuerzo de piezas comprimidas (8), así como para la prolongación de vigas de madera mediante prótesis de madera-madera (9). También hay experiencias para la introducción de refuerzos desde la cara superior ejerciendo un efecto de pretensado para

\section{INTRODUCTION}

The objective of this work is to analyse the behaviour of wooden beams upgraded using steel cross-sections joined to timber with screws, without work on the underside of the flooring.

The rehabilitation of buildings with a timber structure usually requires increased load-bearing capacity in the flooring joists. The biological degradation of timber structures causes the loss of his capacity. Sometimes it is due to changes in regulatory specifications (loads or deflection limitations) which are generally caused by a new use for the building.

There are different possibilities for the upgrading of wooden beams, and they can be grouped into four main methods (1). The first one consists of the addition of a new structural system to support the existing structure (beams or struts to shorten the span of the old beams). However, this system generally needs work on the lower side of the flooring and reduces the height of ceilings.

The second possibility is to increase stiffness and strength by means of the incorporation of reinforcing elements (composite materials, metals or wooden products) which are generally glued to the existing piece (often with epoxy resins). This method is frequently used in the upgrading and consolidation of wooden pieces that have suffered biodegradation (2-5). Usually this problem appears at beam ends rotten in the wall bearing area. Also, this procedure is frequent to reinforce bending elements gluing timber pieces on the upper side (6). The insertion of reinforcing bars inside the cross section of the piece has been experimentally studied from a long time ago. Some authors (7) verified the upgrading of beams using composite material bars and steel cables to reinforce them. The load carrying capacity increased from 32 to $42 \%$ and stiffness from a factor of 1.31 and 1.69. Nevertheless, the procedure seems to be too much complex to use in practice works.

The use of carbon fibre and steel plates has been studied in the reinforcement of compression members (8), as well as for the extension of timber beams by means of adding new pieces of timber (9). Furthermore, there are experiments involving the insertion of reinforcements from the upper surface, introducing a pre-stressed effect 
mejorar la capacidad de carga de vigas de madera (10). En madera laminada encolada se han estudiado los refuerzos con CFRP (Carbon Fiber Reinforced Plastic) y GFRP (Glass Fiber Reinforced Plastic) para mejorar su resistencia a flexión (11). Otro trabajo dedicado al refuerzo de vigas con fendas consistió en el empleo de pletinas metálicas laterales, pernos o refuerzos con FRP (12).

El tercer grupo consiste en la formación de un sistema mixto de madera y hormigón incorporando una capa de hormigón de pequeño espesor en la cara superior del forjado, que queda conectado a la madera. De esta forma, se aumenta enormemente la rigidez del forjado y en menor grado, también la resistencia. Los trabajos en obra se realizan por la cara superior, aunque suele ser conveniente la colocación de un apeo en la planta inferior. La clave del éxito de estas soluciones está en el sistema de conexión entre la madera y el hormigón. Entre los más habituales se encuentran los siguientes (13-14): clavijas metálicas transversales o inclinadas, conectores de superficie, cajeados y otros sistemas. En algunos casos se plantea el refuerzo con hormigón en la cara superior ayudando a la madera con placas metálicas insertadas en el interior (15).

Para el cálculo de los sistemas mixtos puede consultarse el anexo de vigas compuestas con uniones mecánicas del Eurocódigo 5 (16), o la literatura técnica especializada (17-19).

Finalmente, el cuarto grupo consiste en el refuerzo mediante la incorporación de piezas metálicas, generalmente, en la cara inferior, que pueden llegar a sustituir a la madera o a colaborar con ella formando un nuevo sistema estructural; por ejemplo, mediante celosías de simple atirantado (20).

En muchos casos el refuerzo con acero se utiliza como un sistema de consolidación de emergencia más para recuperar la continuidad de la pieza que para mejorar su capacidad portante. Sin embargo, hay poca experiencia sobre la utilización de refuerzos mediante perfiles metálicos conectados a las piezas de madera (21). Éste es el objetivo principal de este trabajo en el cual se plantea el refuerzo con la limitación de intervenir exclusivamente desde la cara superior. Este procedimiento evita los inconvenientes que acompañan a la necesidad de actuar también desde la cara inferior.

\section{MATERIALES Y MÉTODOS}

\subsection{Material de ensayo}

El material de ensayo estaba formado por un conjunto de 30 piezas de madera divididas en tres grupos: 10 piezas de madera laminada encolada de abeto (Picea abies L. Karst) con una sección transversal de 180 × 200 mm y una longitud de $4.000 \mathrm{~mm}$; 10 piezas de madera aserrada de that improves the load bearing capacity of wooden beams (10). Reinforcements with CFRP (Carbon Fibre Reinforced Plastic) and GFRP (Glass Fibre Reinforced Plastic) have been studied to improve the flexural strength of glued laminated timber (11). Another work on the reinforcement of checked beams involved the use of lateral metal plates, bolts or reinforcements with FRP (12).

The third group consists of the configuration of a composite system of timber-concrete, in which a thin slab of concrete is placed over the timber pieces and adequately connected to the wood. In this way stiffness is greatly increased as its strength, although to a lesser degree. Work takes places from the upper side of the flooring, but it is also suitable to include an auxiliary structure in the lower level. The key to the success of these solutions is the connecting element between the timber and concrete. The following connecting elements are generally used (13-14): steel dowels perpendicular or inclined with respect to the contact surface, connectors, slots and other systems (15).

For composite systems design Annex B "Mechanically jointed beams" of Eurocode 5 (16), or specialized technical literature (17-19) can be consulted.

Finally, the fourth group consists of the introduction of steel pieces, generally in the lower face, that can totally replace the structural mission of the timber or aid it, forming a new structural system; for example, by using trusses with steel ties (20).

The use of steel in the upgrading of structures is usually a temporary method of consolidation. Nevertheless, there is little experience with the use of steel pieces connected to timber as a reinforcing system (21). This is the main objective of this work, in which reinforcement works are planned only on the upper surface of the flooring. This procedure avoids the disadvantages associated with works on the lower surface.

\section{MATERIALS AND METHODOLOGY}

\subsection{Testing material}

The test material consisted of a total quantity of 30 pieces of timber divided into three groups: 10 pieces of glued laminated Spruce timber (Picea abies L. Karst) with a cross-section of $180 \times 200 \mathrm{~mm}$ and $4000 \mathrm{~mm}$ in length; 10 pieces of sawn Scotch pine timber (Pinus sylvestris L.) 
pino silvestre (Pinus sylvestris L.) con igual sección y longitud y 10 piezas procedentes de un derribo de edificio con antigüedad aproximada de 120 años de madera del género Pinus, con una sección transversal media de $130 \mathrm{x}$ $150 \mathrm{~mm}$ y una longitud de $3.000 \mathrm{~mm}$.

Los perfiles de refuerzo están fabricados con chapa plegada en forma de $U$ de 4 y $5 \mathrm{~mm}$ de espesor con acero de calidad S275J0 según norma UNE-EN 10025 (22). Las chapas de acero fueron cortadas y taladradas mediante arco de plasma. Esta técnica resulta económica y muy adecuada al dejar las aristas limpias sin rebabas y con un cierto bisel lo que facilita su manipulación en obra.

Para las piezas con sección transversal de 180 × $200 \mathrm{~mm}$ (madera laminada y madera aserrada) se utilizó un perfil en $\mathrm{U}$ (de $5 \mathrm{~mm}$ de espesor) con dos pletinas en la cara inferior (de $4 \mathrm{~mm}$ de espesor) y para las piezas de madera antigua, con una sección menor aproximada de $130 \mathrm{x}$ $150 \mathrm{~mm}$, se utilizó un perfil en $\mathrm{U}$ (de $4 \mathrm{~mm}$ de espesor) con una sola pletina en la cara inferior (de $4 \mathrm{~mm}$ de espesor), Figura 1. Las pletinas están soldadas mediante with the same cross-section and length, together with 10 pieces of solid timber from the dismantling of an old building approximately 120 years old, of the genus Pinus, with an average cross-section of $130 \times 150 \mathrm{~mm}$ and $3000 \mathrm{~mm}$ in length.

The reinforcement pieces are made of cold formed steel with $U$ shapes 4 and $5 \mathrm{~mm}$ thick, with steel of quality S275J0 according to standard EN 10025 (22). The steel plates were cut and perforated by means of gaseous discharge plasma. This technique is cheap and very suitable because it forms clean edges without barbs and bevelled edges making handling on site easier.

For the pieces with a cross-section of $180 \times 200 \mathrm{~mm}$ (glued laminated timber and sawn timber) a U-shaped cross-section (5 $\mathrm{mm}$ thick) with two plates in the lower face ( $4 \mathrm{~mm}$ thick) were used. For the pieces of old timber with a cross-section of approximately $130 \times 150$ $\mathrm{mm}$, a U-shaped cross-section ( $4 \mathrm{~mm}$ thick) with a single plate in the lower face ( $4 \mathrm{~mm}$ thick) were used, Figure 1. The plates are welded by means of continuous arc

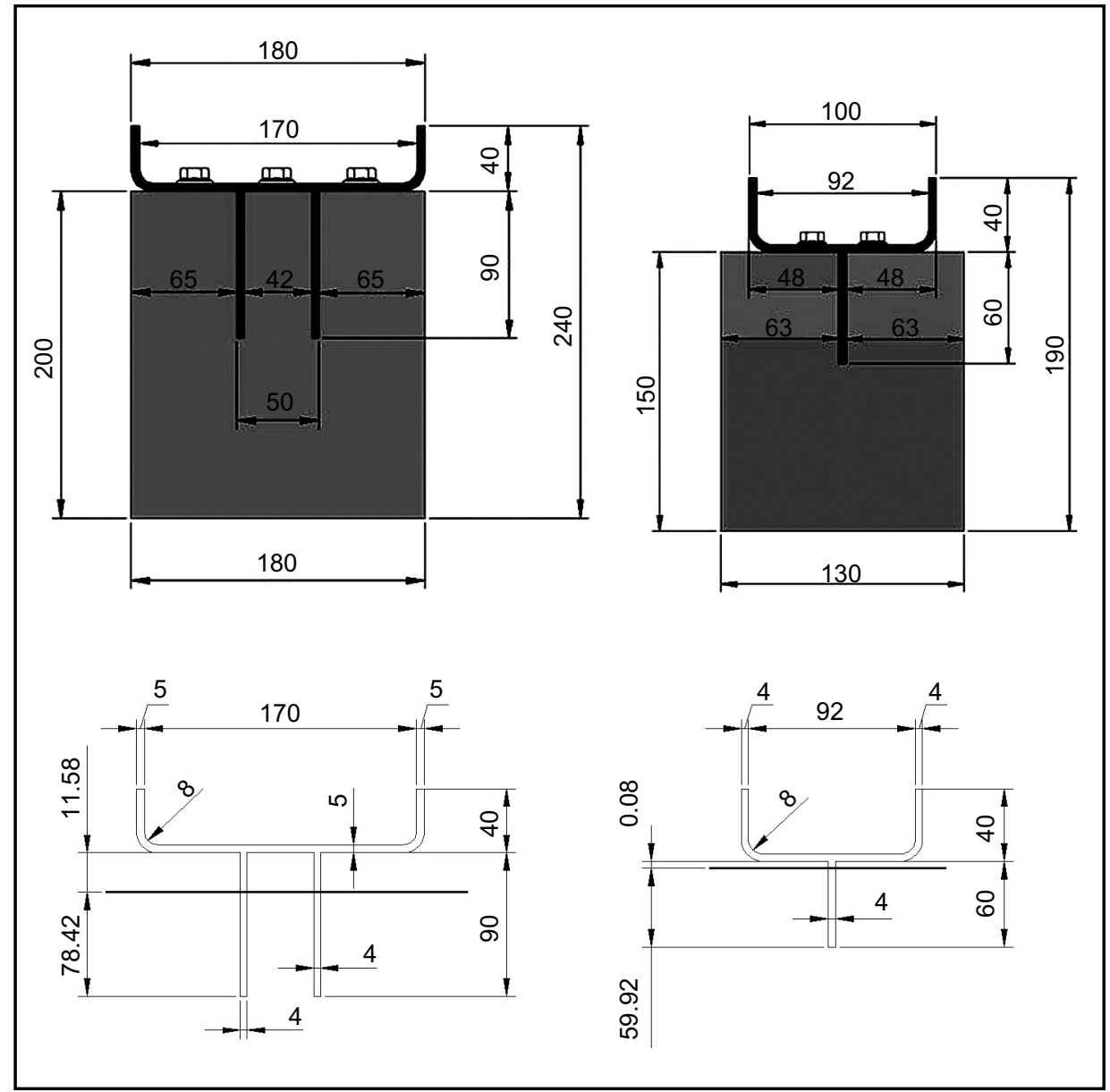

Figura 1. Arriba: Refuerzo con perfil de acero en secciones de 180 × 200 mm y de 130 x 150 mm. Abajo: Perfiles de refuerzo y centros de gravedad.

Figure. 1. Up: Steel cross section reinforcement in timber sections of $180 \times 200 \mathrm{~mm}$ and $130 \times 150 \mathrm{~mm}$. Down: Reinforced steel cross sections and centre of gravity. 
arco de hilo continuo con cordones en cada lado, con una longitud de $30 \mathrm{~mm}$ y una separación de $300 \mathrm{~mm}$.

Como elementos de fijación se han utilizado tirafondos de $8 \mathrm{~mm}$ de diámetro con longitud de $90 \mathrm{~mm}$ para las secciones de 180 × $200 \mathrm{~mm}$ y de $7 \mathrm{~mm}$ de diámetro con longitud de $70 \mathrm{~mm}$ para las secciones de $130 \mathrm{x}$ 150 mm, según la norma DIN 571 (23). La fijación del refuerzo en las secciones de 180 × $200 \mathrm{~mm}$ se realizó mediante la disposición de 3 filas de tirafondos al tresbolillo con una separación en la dirección paralela a la fibra de $100 \mathrm{~mm}$. Para las secciones de madera antigua, de $130 \times 150 \mathrm{~mm}$, se utilizaron 2 filas al tresbolillo con una separación en dirección paralela a la fibra de $100 \mathrm{~mm}$, Figura 2. El agujero en las chapas tenía un diámetro de $10 \mathrm{~mm}$ para el caso de los tirafondos de $8 \mathrm{~mm}$ y de $9 \mathrm{~mm}$ para el caso de los tirafondos de $7 \mathrm{~mm}$. Para la introducción de los tirafondos no se realizó un taladro previo debido a que se observó que no existía problema de fendado en la madera. El apriete se efectuó inicialmente de forma mecánica, pero el apriete final se realizó con una llave manual, siguiendo un orden en zig-zag para lograr un acercamiento entre la madera y el acero más gradual, Figura 2 (abajo). welding on both sides, with a length of $30 \mathrm{~mm}$ and $300 \mathrm{~mm}$ apart.

For the connexion $8 \mathrm{~mm}$ diameter screws $90 \mathrm{~mm}$ long were used for the cross-sections of $180 \times 200 \mathrm{~mm}$, while $7 \mathrm{~mm}$ diameter and $70 \mathrm{~mm}$ long screws were used for the $130 \times 150 \mathrm{~mm}$ sections, according to Standard DIN 571 (23). The connexion of steel cross-section reinforcements to the $180 \times 200 \mathrm{~mm}$ timber sections was executed by means of 3 staggered rows of screws at a distance parallel to the grain of $100 \mathrm{~mm}$. For the old 130 $x 150 \mathrm{~mm}$ timber pieces, 2 rows of staggered screws at a distance parallel to the grain of $100 \mathrm{~mm}$ were used, Figure 2. The plate holes were $10 \mathrm{~mm}$ in diameter for the $8 \mathrm{~mm}$ diameter screws and $9 \mathrm{~mm}$ for those $7 \mathrm{~mm}$ in diameter. No predrilling was needed for the screws because there was not problem of splitting. The initial tightness was mechanically driven but finally a manual wrench was used, in a zigzag sequence, to achieve a progressive approach between timber and steel, Figure 2 (down).

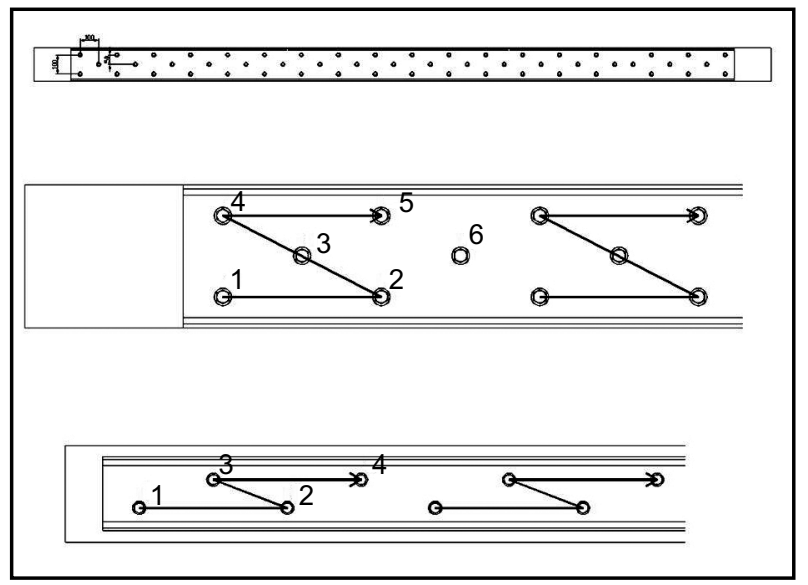

Figura 2. Arriba: Disposición de los tirafondos. Abajo: Secuencia de apriete de los tirafondos.

Figure 2. Up: Screws arrangement. Down: Screws tighten sequence.

Para llegar a las soluciones de refuerzo descritas anteriormente se realizó un análisis de los modelos previos por el método de los elementos finitos con el programa CosmosWorks, ensamblando el refuerzo de acero y la madera en un fichero sobre el que se establecían las condiciones de contacto de acero-acero y acero-madera. Dentro de este estudio de contactos se incluye la disposición de tirafondos que unen los dos materiales para simular la mayor veracidad del ensayo real. El mallado de los elementos se realizó con tetraedros sólidos tridimensionales y ajustes de la trama adaptados a los distintos espesores de las piezas.
In order to design the reinforcement solutions previously described the previous models were analysed using the method of finite elements with the CosmosWorks software, joining the steel reinforcement and timber in a file which included the boundary conditions of steel-steel and steel-timber. This contact study included the disposition of screws to simulate the actual test. The meshed elements were made with three-dimensional solid tetrahedrons and adjustments of the mesh according to the different thickness of pieces. 


\subsection{Método experimental}

En primer lugar se obtuvo el módulo de elasticidad global en el ensayo de flexión según la norma UNEEN 408 (24) de todas las piezas, Figura 3. De acuerdo con esta norma la luz (distancia entre apoyos) debe ser igual a 18 veces el canto de la pieza. Para las piezas de madera laminada y madera aserrada con una sección de 180 × $200 \mathrm{~mm}$ resultaba una luz de 3,6 m. En el caso de la madera antigua la sección variaba para cada pieza, por lo que se tomó una sección de referencia de $130 \times 150 \mathrm{~mm}$, resultado una luz de 2,7 m.

\subsection{Experimental method}

Firstly, the modulus of elasticity was obtained in bending according to Standard EN 408 (24) for all pieces, Figure 3. This standard specified that the span (distance between supports) must be equal to 18 times the depth of the piece. For glued laminated timber and sawn timber pieces with a cross section of $180 \times 200 \mathrm{~mm}$ it means a span of $3.6 \mathrm{~m}$. In case of old timber pieces as the cross section was changing from one to other piece, a reference value of cross section of $130 \times 150 \mathrm{~mm}$ was taken, resulting $2.7 \mathrm{~m}$ span.

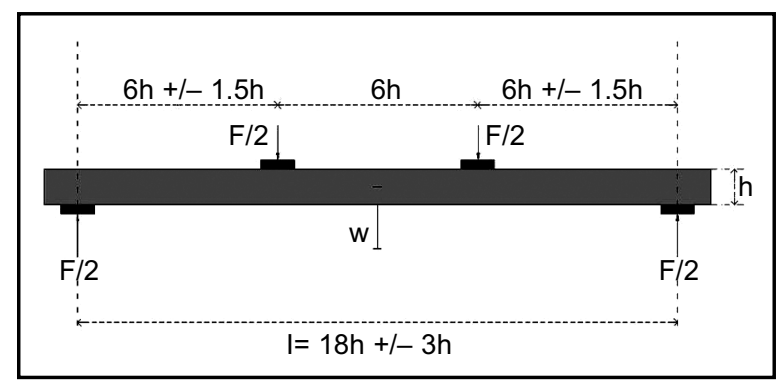

Figura 3. Disposición del ensayo de flexión. Figure 3. Bending test arrangement.

\section{RESULTADOS}

En la Tabla 1 se muestran los valores medios del módulo de elasticidad para cada material. Se observa cómo la madera laminada encolada tiene el mayor valor del módulo de elasticidad y el menor coeficiente de variación $(6,2 \%)$; y la madera antigua, presenta el módulo de elasticidad menor y con el mayor coeficiente de variación (30\%). De esta forma, se puede analizar el resultado del refuerzo con mayor precisión en el caso de la madera laminada, pero también es posible acercarse a los resultados prácticos con materiales más variables como la madera aserrada y antigua.

\section{RESULTS}

The mean values of modulus of elasticity for each material are shown in Table 1. The glued laminated timber material has the highest value of modulus of elasticity and the lower value of coefficient of variation (6.2\%); on the other hand, old timber material has the lower modulus of elasticity and the highest coefficient of variation (30\%). So, it is possible to analyze in a more accurate way the influence of reinforcing in the case of glued laminated timber, but, it is also possible to evaluate the upgrading effect in practice with materials more variables as sawn timber and old timber pieces.

Tabla 1 / Table 1

Valor medio del módulo de elasticidad y coeficiente de variación de los tres materiales ensayados. Mean value of modulus of elasticity and coefficient of variation of tested material.

\begin{tabular}{|c|c|c|c|}
\hline Material & $\begin{array}{c}\text { Número de piezas / } \\
\text { Number of pieces }\end{array}$ & $\begin{array}{c}\text { Módulo de elasticidad / } \\
\text { Modulus of elasticity (N/mm } \mathbf{m}^{\mathbf{2}} \text { ) }\end{array}$ & $\begin{array}{c}\text { Coeficiente de variación / } \\
\text { Coefficient of variation (\%) }\end{array}$ \\
\hline Madera laminada / Glued laminated timber & 10 & 11081 & 6.2 \\
\hline Madera aserrada / Sawn timber & 10 & 7992 & 16 \\
\hline Madera antigua / Old timber & 10 & 6553 & 31 \\
\hline
\end{tabular}

El contenido de humedad de las piezas se evaluó mediante xilohigrómetro de resistencia eléctrica de
The moisture content of pieces was determined by electrical measurement according to the procedure of 
acuerdo con el procedimiento definido en la norma UNEEN 13183-2 (25). El valor medio era de $13,4 \%$ para la madera laminada, 15,9\% para la madera aserrada y $11 \%$ para la madera antigua.

Para cada material se formaron dos grupos de 5 piezas tomados al azar: el grupo A corresponde a las piezas denominadas testigo que no serán reforzadas; y el grupo $B$ que corresponde a las piezas que serán reforzadas con perfiles metálicos.

Las piezas de los grupos A fueron ensayadas a flexión de acuerdo con la norma UNE-EN 408 determinando de nuevo el módulo de elasticidad global, y la tensión y momento de rotura a flexión. En la Tabla 2 se muestran los resultados obtenidos. standard EN 13183-2 (25). The mean value was $13.4 \%$ for glued laminated timber, $15.9 \%$ for sawn timber and $11 \%$ for old timber.

Two groups of 5 pieces selected at random were taken for each material: group $A$ is formed by pieces with no reinforcement, and it is called the reference sample; group $B$ is composed of pieces that will be reinforced with steel pieces.

The pieces of group A were tested in bending according to the standard EN 408 obtaining again the global modulus of elasticity, and the stress and bending moment of rupture. The results are shown in Table 2.

Tabla 2 / Table 2

Módulo de elasticidad, tensión y momento de rotura a flexión de las piezas de los grupos A (testigo). Bending modulus of elasticity and modulus and moment of rupture of pieces from groups A (reference sample).

\begin{tabular}{|c|c|c|c|c|}
\hline Material & $\begin{array}{c}\text { Sección / Cross section } \\
\text { bxh (mm) }\end{array}$ & $\begin{array}{c}\text { Módulo de elasticidad / } \\
\text { Modulus of elasticity } \\
\left(\mathbf{N} / \mathbf{m m}^{2}\right)\end{array}$ & $\begin{array}{c}\text { Tensión de rotura / } \\
\text { Modulus of rupture } \\
\left(\mathbf{N} / \mathbf{m m}^{2}\right)\end{array}$ & $\begin{array}{l}\text { Momento de rotura / } \\
\text { Moment of rupture } \mathrm{M}_{\text {rup }} \\
(\mathrm{kN} \cdot \mathbf{m})\end{array}$ \\
\hline $\begin{array}{c}\text { Madera laminada / } \\
\text { Glued Laminated Timber }\end{array}$ & $180 \times 200$ & $\begin{array}{c}10916 \\
10095 \\
9634 \\
11437 \\
11122\end{array}$ & $\begin{array}{l}40.5 \\
29.6 \\
33.9 \\
41.3 \\
47.7\end{array}$ & $\begin{array}{l}48.570 \\
35.574 \\
40.722 \\
49.590 \\
57.216\end{array}$ \\
\hline \multicolumn{2}{|c|}{$\begin{array}{l}\text { Valor medio / Mean value } \\
\text { Coef. de variación / CoV (\%) }\end{array}$} & $\begin{array}{c}10641 \\
7.0\end{array}$ & $\begin{array}{l}38.6 \\
18.1\end{array}$ & $\begin{array}{c}46.334 \\
18.1\end{array}$ \\
\hline $\begin{array}{l}\text { Madera aserrada / } \\
\text { Sawn Timber }\end{array}$ & $180 \times 200$ & $\begin{array}{l}7003 \\
8317 \\
6869 \\
8214 \\
9210\end{array}$ & $\begin{array}{l}23.2 \\
33.0 \\
25.2 \\
31.0 \\
42.3\end{array}$ & $\begin{array}{l}27.840 \\
39.552 \\
30.276 \\
37.164 \\
50.796\end{array}$ \\
\hline \multicolumn{2}{|c|}{$\begin{array}{l}\text { Valor medio / Mean value } \\
\text { Coef. de variación / CoV (\%) }\end{array}$} & $\begin{array}{c}7923 \\
12.4\end{array}$ & $\begin{array}{l}30.9 \\
24.3\end{array}$ & $\begin{array}{c}37.126 \\
24.3\end{array}$ \\
\hline Madera antigua / Old timber & $\begin{array}{l}142 \times 156 \\
141 \times 165 \\
122 \times 156 \\
149 \times 169 \\
132 \times 151\end{array}$ & $\begin{array}{c}4219 \\
7225 \\
7113 \\
7580 \\
10521\end{array}$ & $\begin{array}{l}10.1 \\
25.9 \\
23.6 \\
24.5 \\
39.0\end{array}$ & $\begin{array}{c}5.805 \\
16.542 \\
11.700 \\
17.348 \\
19.575\end{array}$ \\
\hline \multicolumn{2}{|c|}{$\begin{array}{l}\text { Valor medio / Mean value } \\
\text { Coef. de variación / CoV }(\%)\end{array}$} & $\begin{array}{c}7332 \\
30.5\end{array}$ & $\begin{array}{l}24.6 \\
41.7\end{array}$ & $\begin{array}{c}14.194 \\
38.7\end{array}$ \\
\hline
\end{tabular}

Las piezas de los grupos B fueron ensayadas a flexión según la norma UNE-EN 408 para la determinación de la rigidez a flexión inicial $(\mathrm{E} \cdot \mathrm{I})_{\text {in. }}$. Posteriormente, fueron reforzadas con los perfiles metálicos definidos en el apartado de Materiales y sometidos a ensayo de flexión según la misma norma, determinando la rigidez a flexión eficaz de la pieza reforzada (E.I $)_{\text {ef }}$ y el momento de rotura en flexión (Mrup). En la Tabla 3 se muestran los resultados obtenidos.
The pieces in the $B$ groups were bending tested according to Standard EN 408 in order to determine the initial bending stiffness $(E \cdot I)_{i n}$. They were then reinforced with steel pieces as described in section 2, and they were bending tested to obtain the effective bending stiffness of the reinforced beams $(E \cdot I)_{\text {ef }}$ and the bending rupture moment (Mrup). Table 3 shows the results. 
Tabla 3 / Table 3

Rigidez a flexión inicial y eficaz (reforzada) y momento de rotura a flexión de las piezas de los grupos B (reforzada). Initial and effective reinforced bending stiffness and moment of rupture of pieces from groups $B$ (reinforced sample).

\begin{tabular}{|c|c|c|c|c|c|}
\hline \multirow[b]{2}{*}{ Material } & \multirow[b]{2}{*}{ Pieza / Piece } & \multirow{2}{*}{$\begin{array}{l}\text { Sección / } \\
\text { Cross section } \\
\text { bxh (mm) }\end{array}$} & \multicolumn{2}{|c|}{$\begin{array}{l}\text { Rigidez a flexión / Bending stiffness } \\
\left(\mathrm{kN} \cdot \mathrm{m}^{2}\right)\end{array}$} & \multirow{2}{*}{$\begin{array}{c}\text { Momento de rotura / } \\
\text { Moment of rupture } \\
\mathrm{M}_{\text {rup }}(\mathbf{k N} \cdot \mathbf{m})\end{array}$} \\
\hline & & & $\begin{array}{l}\text { Inicial / Initial } \\
(\mathrm{E} \cdot \mathrm{I})_{\text {in }}\end{array}$ & $\begin{array}{l}\text { Reforzada / } \\
\text { Reinforced } \\
(\mathrm{E} \cdot \mathrm{I})_{\mathrm{ef}}\end{array}$ & \\
\hline $\begin{array}{l}\text { Madera laminada / } \\
\text { Glued Laminated Timber }\end{array}$ & $\begin{array}{l}1 \\
2 \\
3 \\
4 \\
5\end{array}$ & $180 \times 200$ & $\begin{array}{l}1225 \\
1247 \\
1441 \\
1366 \\
1394\end{array}$ & $\begin{array}{l}1610 \\
2785 \\
2128 \\
1876 \\
1717\end{array}$ & $\begin{array}{l}55.800 \\
52.410 \\
76.800 \\
70.380 \\
60.480\end{array}$ \\
\hline \multicolumn{3}{|c|}{$\begin{array}{l}\text { Valor medio / Mean value } \\
\text { Coef. de variación / } \operatorname{CoV}(\%)\end{array}$} & $\begin{array}{c}1335 \\
7.0\end{array}$ & $\begin{array}{l}2023 \\
23.2\end{array}$ & $\begin{array}{c}63.174 \\
16.1\end{array}$ \\
\hline $\begin{array}{l}\text { Madera aserrada / } \\
\text { Sawn Timber }\end{array}$ & $\begin{array}{l}1 \\
2 \\
3 \\
4 \\
5\end{array}$ & $180 \times 200$ & $\begin{array}{c}910 \\
1290 \\
852 \\
756 \\
1021\end{array}$ & $\begin{array}{l}1797 \\
2274 \\
1756 \\
1647 \\
2082\end{array}$ & $\begin{array}{l}40.320 \\
86.940 \\
52.500 \\
50.280 \\
63.600\end{array}$ \\
\hline \multicolumn{3}{|c|}{$\begin{array}{l}\text { Valor medio / Mean value } \\
\text { Coef. de variación / CoV }(\%)\end{array}$} & $\begin{array}{l}966 \\
21.2\end{array}$ & $\begin{array}{c}1911 \\
13.5\end{array}$ & $\begin{array}{c}58.728 \\
30.3\end{array}$ \\
\hline $\begin{array}{l}\text { Madera antigua / } \\
\text { Old timber }\end{array}$ & $\begin{array}{l}1 \\
2 \\
3 \\
4 \\
5\end{array}$ & $\begin{array}{l}129 \times 146 \\
111 \times 149 \\
149 \times 163 \\
123 \times 161 \\
129 \times 162\end{array}$ & $\begin{array}{l}140 \\
201 \\
385 \\
374 \\
203\end{array}$ & $\begin{array}{l}363 \\
407 \\
607 \\
657 \\
410\end{array}$ & $\begin{array}{c}9.315 \\
14.895 \\
24.750 \\
26.775 \\
14.400\end{array}$ \\
\hline \multicolumn{3}{|c|}{$\begin{array}{l}\text { Valor medio / Mean value } \\
\text { Coef. de variación / CoV }(\%)\end{array}$} & $\begin{array}{l}261 \\
42.8\end{array}$ & $\begin{array}{l}489 \\
27.2\end{array}$ & $\begin{array}{c}18.027 \\
41 . .2\end{array}$ \\
\hline
\end{tabular}

\section{DISCUSIÓN}

El refuerzo de las vigas produce un aumento de la rigidez a flexión que puede evaluarse como un factor de aumento de la rigidez (rigidez reforzada/rigidez inicial) de 1,45 para la madera laminada encolada, 1,98 para la madera aserrada y de 1,87 para la madera antigua. En la Figura 4 se muestra la variación de rigidez para cada pieza.

La capacidad de carga de las piezas reforzadas (grupo B) es superior comparada con la de las piezas de referencia (grupo A). El aumento de capacidad de carga a flexión puede estimarse como el factor que relaciona el valor medio del momento de rotura de las piezas reforzadas y el de las de referencia. Este factor resulta igual a 1,36 para la madera laminada, 1,58 para la madera aserrada y 1,27 para la madera antigua.

El momento de inercia de los perfiles metálicos de refuerzo, $\mathrm{I}_{\mathrm{s}}$ es igual a $1.906 .378 \mathrm{~mm}^{4}$ para el perfil con dos pletinas inferiores y $460.848 \mathrm{~mm}^{4}$ para el perfil con una única pletina (Figura 1-abajo). La rigidez a flexión de estos perfiles, considerando un módulo de elasticidad para el acero Es $=210.000 \mathrm{~N} / \mathrm{mm}^{2}$, es de 400 y $96,77 \mathrm{kN} \cdot \mathrm{m}^{2}$, respectivamente.

\section{DISCUSSION}

The reinforcing of beams produces an increment of bending stiffness defined as an increment factor (reinforced stiffness/initial stiffness) of 1.45 for glued laminated timber, 1.98 for sawn timber and 1.87 for old timber. The increment of stiffness is shown in Figure 4 for each piece.

The load carrying capacity of reinforced pieces (group B) is greater than load carrying capacity of reference pieces (group A). This increment of bending capacity may be evaluated as a factor between the mean value of bending moment of rupture of reinforced pieces and the mean value of reference pieces. This factor is 1.36 for glued laminated timber, 1.58 for sawn timber and 1.27 for old timber.

The second moment of area of reinforcing steel cross section, $I_{s}$ is $1906378 \mathrm{~mm}^{4}$ for the cross section with two lower plates and $460848 \mathrm{~mm}^{4}$ for the cross section with one plate, Figure 1. The bending stiffness of these cross sections, considering a modulus of elasticity for steel $E_{S}=210000 \mathrm{~N} / \mathrm{mm}^{2}$, is 400 and $96.77 \mathrm{kN} \cdot \mathrm{m}^{2}$, respectively. 


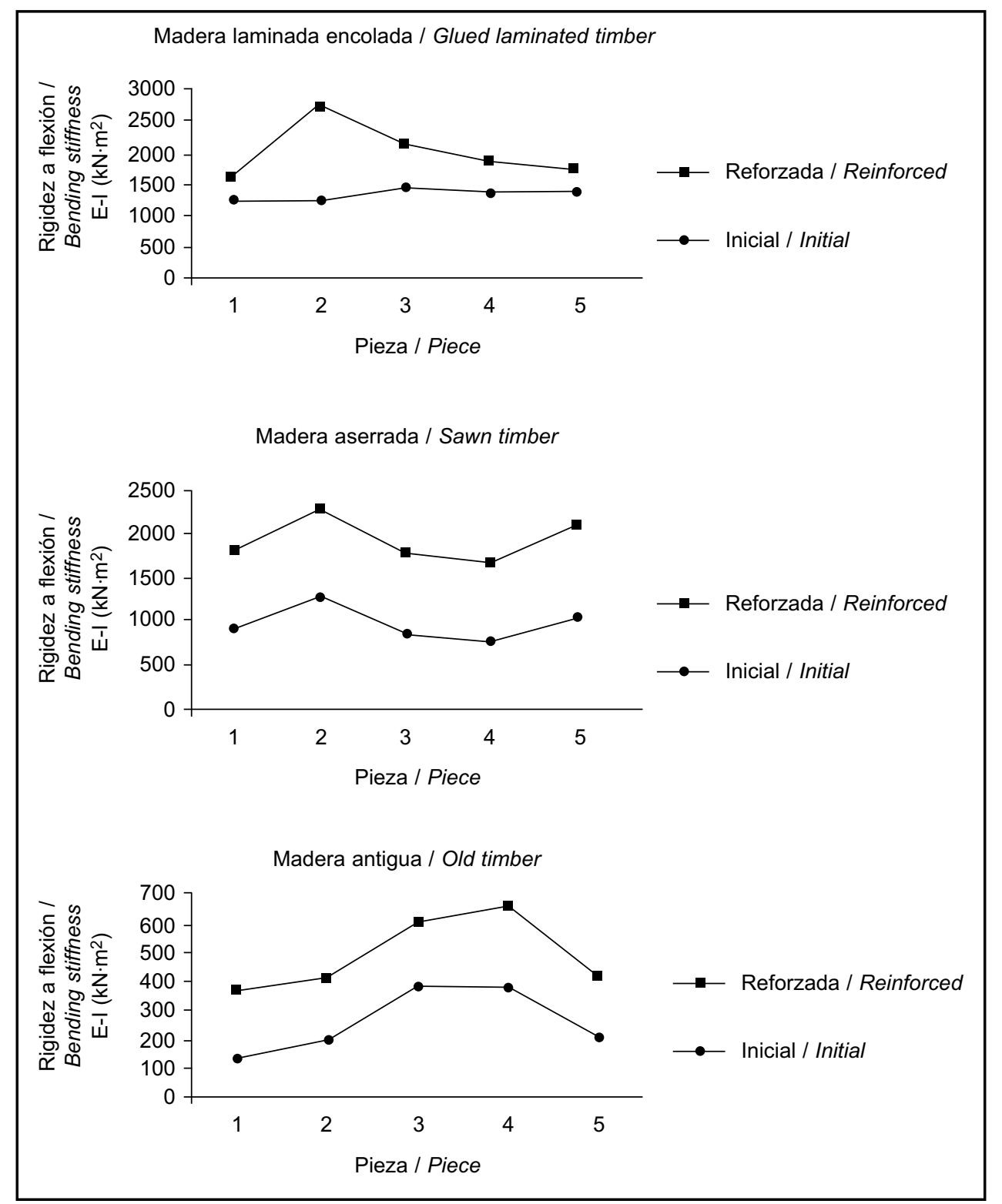

Figura 4. Aumento de la rigidez a flexión para cada pieza de los tres materiales.

Figure 4. Increase of bending stiffness for each piece of the three materials.

La sección de madera quedará reducida por las ranuras para la inserción de las pletinas metálicas en un grueso igual al espesor de las pletinas más una holgura de $2 \mathrm{~mm}$. Así, para el perfil de doble pletina la pérdida de sección en la parte superior será de 14 × $90 \mathrm{~mm}$ y para el perfil de una pletina de $6 \times 60 \mathrm{~mm}$. En la Tabla $4 \mathrm{se}$ muestra la rigidez a flexión de los perfiles metálicos, $\mathrm{E}_{\mathrm{s}} \mathrm{I}_{\mathrm{s}}$; además, se recogen las rigideces a flexión de las piezas de madera, $E_{w} I_{W}$, siendo $E_{w}$ el módulo de elasticidad $e$ $I_{W}$ el momento de inercia de las piezas de madera. La rigidez del conjunto puede variar entre un valor mínimo sin efecto solidario y un valor máximo admitiendo que la conexión fuera rígida. El valor mínimo, $(\mathrm{EI})_{\min }$ es la suma de las rigideces de ambos materiales $\left(E_{S} I_{S}+E_{w} I_{w}\right)$ y el valor máximo $(\mathrm{EI})_{\max }$ se ve incrementado por el efecto
The timber section is reduced by the slots for the insertion of steel plates in a quantity equal to the thickness of plates plus a looseness of $2 \mathrm{~mm}$ and a depth equal to the plate width. Therefore, for the double plate section the loss of section in the upper side is $14 \times 90 \mathrm{~mm}$ and for the single plate section is $6 \times 60$ $\mathrm{mm}$. Table 4 shows the bending stiffness of steel crosssection, $E_{S} I_{S}$, where $E_{S}$ is the steel modulus of elasticity and $I_{S}$ the second moment of area of the steel crosssection; also it is shown the bending stiffness of timber piece, $E_{W} I_{W}$, where $E_{W}$ is the modulus of elasticity and $I_{W}$ the second moment of area of the timber piece. The stiffness of the whole piece (timber + steel) may range from a minimum value without solidity effect and a maximum value supposing a perfect rigid connexion 
de solidaridad de ambos materiales. En la Tabla 4 se incluyen estos valores así como la rigidez eficaz obtenida en el ensayo. between both materials. The minimum value, $(E I)_{\min }$ is the sum of the stiffness of both pieces, independently, $\left(E_{s} I_{S}+E_{w} I_{w}\right)$ and the maximum value is equal this previous value plus the increment of the second moment of areas respect to the principal axis of the whole section for each material, (EI) max. Table 4 shows these values and the effective stiffness obtained by test $(E I)_{\text {ef }}$.

Tabla 4 / Table 4

Rigideces a flexión.

Bending stiffness.

\begin{tabular}{|c|c|c|c|c|c|c|}
\hline \multirow[b]{2}{*}{ Material } & \multirow[b]{2}{*}{ Pieza / Piece } & \multicolumn{5}{|c|}{ Rigidez a flexión / Bending stiffness $\left(\mathbf{k N} \cdot \mathrm{m}^{2}\right)$} \\
\hline & & Acero / Stee/ $\mathbf{E}_{\mathbf{s}} \mathbf{I}_{\mathbf{s}}$ & $\begin{array}{c}\text { Madera / Timber } \\
\mathbf{E}_{\mathbf{w}} \mathbf{I}_{\mathbf{w}}\end{array}$ & $(E I)_{\min }$ & $(E I)_{\text {ef }}$ & $(E I)_{\max }$ \\
\hline $\begin{array}{l}\text { Madera laminada / } \\
\text { Glued Laminated Timber }\end{array}$ & $\begin{array}{l}1 \\
2 \\
3 \\
4 \\
5\end{array}$ & 400 & $\begin{array}{l}1176 \\
1197 \\
1383 \\
1312 \\
1338\end{array}$ & $\begin{array}{l}1576 \\
1597 \\
1783 \\
1712 \\
1738\end{array}$ & $\begin{array}{l}1610 \\
2785 \\
2128 \\
1876 \\
1717\end{array}$ & $\begin{array}{l}3121 \\
3157 \\
3462 \\
3 \text { 346 } \\
3390\end{array}$ \\
\hline $\begin{array}{l}\text { Madera aserrada / } \\
\text { Sawn Timber }\end{array}$ & $\begin{array}{l}1 \\
2 \\
3 \\
4 \\
5\end{array}$ & 400 & $\begin{array}{c}873 \\
1238 \\
818 \\
726 \\
980\end{array}$ & $\begin{array}{l}1273 \\
1638 \\
1218 \\
1126 \\
1380\end{array}$ & $\begin{array}{l}1797 \\
2274 \\
1756 \\
1647 \\
2082\end{array}$ & $\begin{array}{l}2578 \\
3225 \\
2471 \\
2287 \\
2776\end{array}$ \\
\hline $\begin{array}{l}\text { Madera antigua / } \\
\text { Old timber }\end{array}$ & $\begin{array}{l}1 \\
2 \\
3 \\
4 \\
5\end{array}$ & 96.77 & $\begin{array}{l}137 \\
195 \\
377 \\
365 \\
198\end{array}$ & $\begin{array}{l}234 \\
292 \\
474 \\
462 \\
295\end{array}$ & $\begin{array}{l}363 \\
407 \\
607 \\
657 \\
410\end{array}$ & $\begin{array}{c}532 \\
678 \\
1079 \\
1052 \\
706\end{array}$ \\
\hline
\end{tabular}

Se observa cómo la rigidez eficaz obtenida por ensayo se sitúa entre los valores mínimos y máximos posibles con la excepción de la probeta número 5 de madera laminada encolada, Figura 5, que queda ligeramente por debajo del mínimo. El incremento de la rigidez con respecto a la rigidez mínima en relación a la rigidez máxima que podría alcanzarse se recoge para los valores medios de cada material en la Tabla 5 . Se observa
The effective stiffness obtained by test is in between the minimum and maximum values with the exception of specimen number 5 of glued laminated timber, Figure 5, that is slightly lower than minimum. The stiffness increment with respect to the minimum stiffness in relation to the maximum stiffness increment is shown in Table 5 for the mean values of each material. This increment is much lower in glued laminated timber

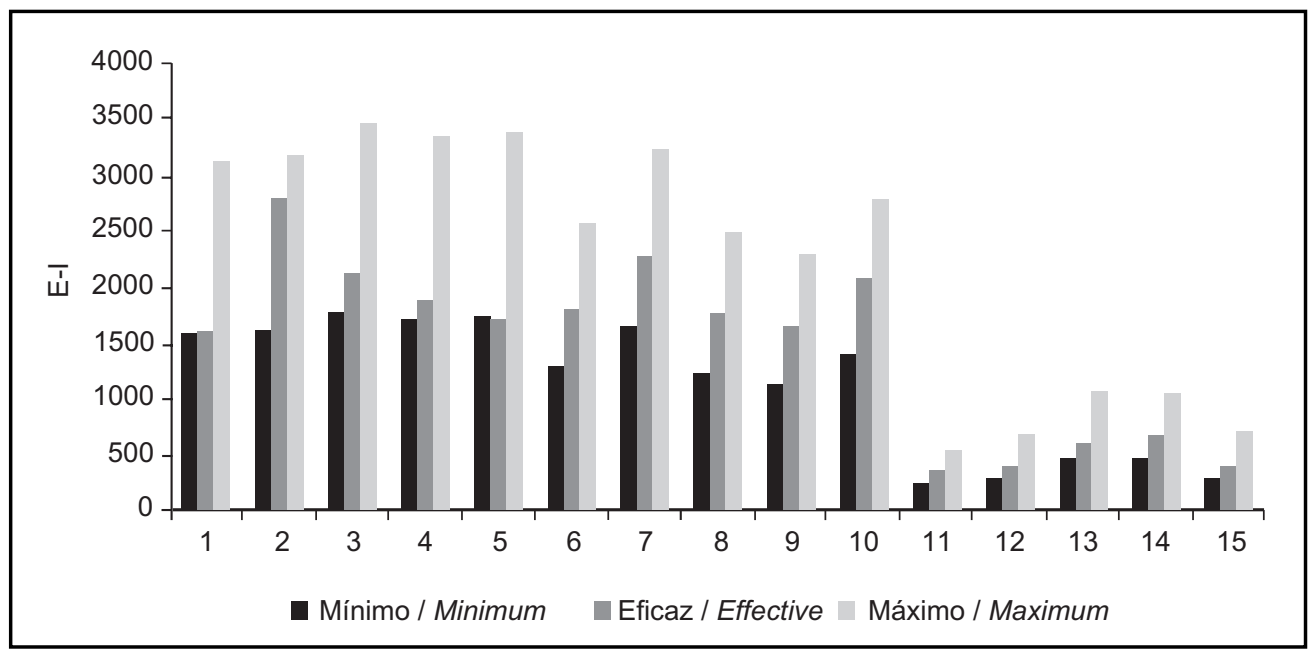

Figura 5. Rigideces a flexión E·I en $\mathrm{kN} \cdot \mathrm{m}^{2}$ mínima, eficaz (obtenida en ensayo) y máxima para todas las piezas (1 a 5 madera laminada, 6 a 10 madera aserrada y 11 a 15 madera antigua).

Figure 5. Bending stiffness $E \cdot I$ in $\mathrm{kN} \cdot \mathrm{m}^{2}$ minimum, effective (obtained by test) and maximum for all pieces ( 1 to 5 glued laminated timber, 6 to 10 sawn timber and 11 to 15 old timber). 
Tabla 5 / Table 5

Incremento medio de la rigidez con respecto a la rigidez mínima.

Mean stiffness increment respect to minimum stiffness.

\begin{tabular}{|c|c|c|}
\hline Material & $\frac{(E I)_{\text {ef }}-(E)_{\min }}{\left(E I_{\max }-(E)_{\min }\right.} \cdot \mathbf{1 0 0}$ & $\begin{array}{c}\text { Coeficiente de variación / Coefficient of variation } \\
\text { (\%) }\end{array}$ \\
\hline Madera laminada / Glued laminated timber & 22 & 147 \\
\hline Madera aserrada / Sawn timber & 44 & 10 \\
\hline Madera antigua / Old timber & 31 & 26 \\
\hline
\end{tabular}

cómo este incremento es mucho menor para la madera laminada encolada y además, con un coeficiente de variación muy elevado, comparado con la madera maciza.

De los resultados puede concluirse que la rigidez del conjunto se sitúa en un nivel relativamente bajo con respecto al máximo; entre el 31 y el $44 \%$ para la madera maciza. Sin embargo, para la madera laminada encolada desciende al 22\%. Esta baja rigidez de la conexión entre la madera y la pieza de acero puede explicarse por la existencia de holguras en los agujeros de los taladros donde se alojan los tirafondos, que permiten cierto deslizamiento entre ambos materiales. La madera laminada estaba fabricada con abeto (Picea abies L. Karst) que presenta una densidad inferior a la de la madera de pino utilizada en las restantes probetas. Esta menor densidad puede justificar la diferencia de comportamiento al dar lugar a una conexión más flexible.

La rotura de las piezas se alcanzaba por el fallo de la zona traccionada en la pieza de madera. En ese momento el perfil de refuerzo no presentaba signos de pandeo local en las alas del perfil en $U$, ni tampoco se observaba deformación o rotura en los tirafondos. La rotura se producía por lo general en zonas próximas a nudos y en un $27 \%$ de los casos en una sección fuera del tercio central.

\section{CONCLUSIONES}

El refuerzo de las vigas con los perfiles metálicos permite aumentar la rigidez de las mismas en un factor igual a 1,45 para las piezas de madera laminada, 1,98 para las piezas de madera aserrada y de 1,87 para las piezas de madera antigua.

La capacidad resistente de las vigas (momento de rotura) se incrementa en un factor igual a 1,36 para la madera laminada, 1,58 para la madera aserrada y 1,27 para la madera antigua. Los coeficientes de variación de las piezas reforzadas resultan prácticamente iguales a los de las piezas sin reforzar.

La conexión entre el perfil en $U$ de acero y la madera mediante los tirafondos alcanza una rigidez relativamente and with a high coefficient of variation, compared with solid timber.

According to the results, the stiffness of the whole cross section is relatively low with respect to the maximum value; 31 to $44 \%$ in solid timber. However, in glued laminated timber it decreases to $22 \%$. This low stiffness of the connexion between timber and steel, may be explained because the holes for the screws have a looseness allowing sliding between both materials. Glued laminated timber was manufactured with spruce (Picea abies L. Karst) and this wood has a density lower than pine used in the rest of specimens. The lower density may explain the different behaviour as a result of a more flexible connexion.

The rupture of beams was produced by failure in tension side of the timber piece. Then, the steel cross section did not have signals of local buckling of flanges of the $U$ shape section, and there was not deformation or failure of screws. The failure was, in general, close to knotty areas and in $27 \%$ of cases in a section out of central third of span.

\section{CONCLUSIONS}

The reinforcement of beams with steel pieces increases the bending stiffness by a factor of 1.45 for glued laminated timber, 1.98 for sawn timber and 1.87 for old timber beams.

The load-bearing capacity of beams (bending moment of rupture) increased by a factor of 1.36 for glued laminated timber, 1.58 for sawn timber and 1.27 for old timber. The coefficient of variation of reinforced pieces is in practice equal to those of pieces without reinforcement.

The screwed connexion between U-shaped crosssections and timber has a relatively low stiffness in 
baja, comparada con la rigidez máxima que podría en teoría alcanzarse. Esta conexión resulta de menor eficacia en las piezas de madera laminada encolada, posiblemente debido a su menor densidad. En general, puede pensarse en una mejora de la rigidez mediante el encolado con resinas epoxi de las pletinas que se introducen en la madera. Otro procedimiento para mejorar la conexión puede ser la utilización de agujeros sin holgura para insertar los tirafondos, pero daría lugar a dificultades en la ejecución.

El sistema de refuerzo es viable en obra por la facilidad de trabajo y los resultados obtenidos. Se considera de interés aumentar el número de ensayos mejorando los aspectos de las conexiones entre materiales, para confirmar los resultados obtenidos. También se considera de interés la adaptación de este sistema de refuerzo para el caso frecuente de daños por pudrición en los apoyos de las vigas.

\section{AGRADECIMIENTOS}

Laboratorio de Estructuras de Madera del CIFOR-INIA, Madrid. comparison with the maximum stiffness that can be attained in theory. This connexion is less effective in glued laminated timber pieces, probably due to the lower density of Spruce. It would be possible to improve the stiffness by means of gluing with epoxy resins of plates inserted into timber. Other possibility to improve the connexion could be the use of screw holes without looseness, but it would increase the difficulty of execution at work.

This reinforcement system is useful in practice because it is easy to apply in situ and gives good results. It would be necessary to increase the number of tests improving the stiffness of connection between materials to confirm the results obtained. It would also be of practical interest to study the use of this system in the frequent case of deterioration at beam ends due to rotting.

\section{ACKNOWLEDGMENTS}

Laboratorio de Estructuras de Madera del CIFOR-INIA, Madrid.

\section{BIBLIOGRAFÍA / BIBLIOGRAPHY}

(1) Arriaga, F.; Peraza, F.; Esteban, M.; Bobadilla, I. y García, F.: Intervención en estructuras de madera. Editorial AITIM, Madrid (2002), $476 \mathrm{pp}$.

(2) Anon: "The age of resin". The Architects Journal, Feb. (1982), pp. 56-58.

(3) Landa, M.: "Nuevas técnicas de reparación de estructuras de madera. Elementos flexionados. Aporte de madera-Unión encolada I. Metodología de puesta en obra". Revista de Edificación no 28, Pamplona (1999), pp. 32-38.

(4) Landa, M.: "Nuevas técnicas de reparación de estructuras de madera. Elementos flexionados. Aporte de madera-Unión encolada II. Metodología de puesta en obra". Revista de Edificación no 29, Pamplona (1999), pp. 30-36.

(5) Mettem, C. J., Page, A. V. y Robinson, G. C.: "Repair of structural timbers. Part I: Test on experimental beam repairs". TRADA, Reino Unido (1993).

(6) Navarrete, I.: Palacio de la Aljafería de Zaragoza. Refuerzo de la viguería. AITIM, no 183 (1996), pp. 61-63.

(7) Cigni, G.; Amato, R. O.; Chigi, P.; Perrone, U.; Rocchi, P.: Nuove tecniche di consolidamento di trave in legno. Edizione Kappa. Roma (1981), 53 pp.

(8) Tanaka, H.; Idota, H.; Ono, T.: Evaluation of buckling strength of hibrid timber columns reinforced with steel plates and carbon fiber sheets. Proceedings of 9th World Conference on Timber Engineering WCTE 2006. Portland, Oregon, USA (2006).

(9) Smedley, D.; Alam, P.; Ansell, M. P.: George Street, St. Albans, UK - a case study in the repair of historic timber structures using bonded-in pultruded plates. Proceedings of 9th World Conference on Timber Engineering WCTE 2006. Portland, Oregon, USA (2006).

(10) Martín, L.; Properzi, M.; Pichelin, F.; Triboulot, P.: Pre-stressed FRP for the in-situ strengthening of timber structures. Proceedings of 9th World Conference on Timber Engineering WCTE 2006. Portland, Oregon, USA (2006).

(11) Alam, P.; Ansell, M. P.; Smedley, D.: Repair of fractured spruce beams with bonded-in reinforcements. Proceedings of 9th World Conference on Timber Engineering WCTE 2006. Portland, Oregon, USA (2006).

(12) (12) Akbiyik, A.; Lamanna, A. J. and Micah Hale, W.: "Feasibility investigation of the shear repair of timber stringers with horizontal splits". Construction and building materials 21 (2007), pp. 991-1000.HYPERLINK "http://dx.doi.org/10.1016/j.conbuildmat. 2006.03.004"doi:10.1016/j.conbuildmat.2006.03.004

(13) Ceccotti, A.: Timber-concrete composite structures. Timber Engineering. STEP 2, E13. Centrum Hout, Holanda (1995).

(14) Bottinelli, G.: "Habitat System Beton: ragioni, certificazione, risultati sperimentali". Adrastea, no 16 (2000).

(15) Tampone, G.: Restauro strutturale con lamine metalliche dei solai lignei della sede del Genio Civile di Firenze. Il restauro del legno, Volume primo. Nardini Editore, Florencia (1989), pp. 263-281. 
(16) UNE-EN 1995-1-1. Proyecto de Estructuras de Madera. Parte 1-1: General - Reglas comunes y reglas para la edificación.

(17) Cecchi, A.: Rinforzo di solai in legno mediante soletta collaborante in calcestruzzo armato con collegamenti di tipo elastico. Il restauro del legno, Volume secondo. Nardini Editore, Florencia (1989), pp. 201-213.

(18) Kreuzinger, H.: Mechanically jointed beams and columns. Timber Engineering. STEP 1, B11. Centrum Hout Holanda (1995). (19) Fernández-Cabo, J. L.; Fernández-Lavandera, J. and Ávila-Jalvo, J. M.: Wood-concrete and wood-wood mixed beams: a rational basis for selecting the connections. Proceeding of 9th World Conference on Timber Engineering. Portland, Oregon, USA (2006).

(20) Gramegna, F. y Marampon, F.: "Dal rilievo del degrado per incendio alle suelte di consolidamento". Adrastea 7/96 (1996), pp. 40-47.

(21) González-Bravo, C.: Recuperación de la capacidad mecánica en piezas de madera solicitadas a flexión en estructuras tradicionales operando por la cara superior mediante refuerzos y prótesis metálicas. Tesis Doctoral, Universidad Politécnica de Madrid (2007).

(22) UNE-EN 10025-1: Productos laminados en caliente de aceros para estructuras. Parte 1: Condiciones técnicas generales de suministro. (Hot rolled products of structural steels - Part 1: General technical delivery conditions).

(23) DIN 571: Tirafondos para madera con cabeza hexagonal screws (Hexagon head wood).

(24) UNE-EN 408: Estructuras de madera. Madera aserrada y madera laminada encolada para uso estructural. Determinación de algunas propiedades físicas y mecánicas (Timber structures. Sawn timber and glued laminated timber for structural use. Determination of some physical and mechanical properties) (2004).

(25) EN 13183-2: Contenido de humedad de una pieza de madera aserrada. Parte 2: Estimación mediante el método de la resistencia eléctrica (Moisture content of a piece of sawn timber. Part 2: Estimation by electrical resistance method) (2002). 